APEM
Advances in Production Engineering \& Management

Volume 10 | Number 2 | June 2015 | pp 97-107

http://dx.doi.org/10.14743/apem2015.2.195
ISSN 1854-6250

Journal home: apem-journal.org

Original scientific paper

\title{
Wear characteristics of heat-treated Hadfield austenitic manganese steel for engineering application
}

\author{
Agunsoye, J.O..$^{\mathrm{a},{ }^{*},}$, Talabi, S.I. ${ }^{\mathrm{b}}$, Bello, $0 .^{\mathrm{a}}$ \\ ${ }^{a}$ Department of Metallurgical and Materials Engineering, University of Lagos, Akoka, Nigeria \\ ${ }^{b}$ Department of Materials and Metallurgical Engineering, University of Ilorin, Ilorin, Nigeria
}

\begin{abstract}
A B S T R A C T
The wear behaviour was investigated of heat treated Hadfield austenitic manganese steel (HAMnS). The wear test was carried out using spin on disc apparatus under different loading loads and speed conditions. A scanning electron microscopy (SEM), an X-ray diffractometer and micro-hardness testing machines were used for examining the morphology, compositions and to measure the hardness of the manganese steel, respectively. The results of the wear test showed that the sliding speed-time interactions effect gave the most significant effect on the austenitic manganese steel. The solution heat treatment programme increased the wear resistance of the alloy steel under increasing load, speed and time. The as-cast microstructure was characterized by heterogeneously dispersed chromium carbides second phase particle, and was responsible for the observed non-uniform wear rate. In regard to the solution heat treated HAMnS, the segregated carbides were dissolved at $1050{ }^{\circ} \mathrm{C}$ and uniformly dispersed within the matrix of its microstructure after rapid water quenching to room temperature. This later development was responsible for the uniform and improved wear resistance of the manganese steel casting. This work demonstrated significantly that there is a direct relationship between the second phase carbides, their distribution and the wear rate pattern of HAMnS casting.
\end{abstract}

(C) 2015 PEI, University of Maribor. All rights reserved.

\section{ARTICLE INFO}

Keywords:

Manganese steel

Wear behaviour

Solution heat treatment

Microstructure

Hardness

*Corresponding author:

jagunsoye@unilag.edu.ng

(Agunsoye, J.0.)

Article history:

Received 18 November 2014

Revised 30 March 2015

Accepted 7 April 2015 


\title{
Značilnosti obrabe toplotno obdelanega Hadfield avstenitenega manganovega jekla za inženirske aplikacije
}

\author{
Agunsoye, J.O..$^{\mathrm{a},{ }^{*}}$, Talabi, S.I. ${ }^{\mathrm{b}}$, Bello, $0 .^{\mathrm{a}}$ \\ ${ }^{a}$ Department of Metallurgical and Materials Engineering, University of Lagos, Akoka, Nigeria \\ ${ }^{\mathrm{b}}$ Department of Materials and Metallurgical Engineering, University of Ilorin, Ilorin, Nigeria
}

\section{POVZETEK}

V prispevku so prikazane značilnosti obrabe toplotno obdelanega Hadfield avstenitenega manganovega jekla (HAMnS). Test obrabe je bil izveden z uporabo aparata $\mathrm{z}$ vrtečim diskom z različnimi hitrostmi in pod različnimi obremenitvami. Za preizkušanje morfologije, sestave materiala in za merjenje trdote so bili uporabljeni vrstični elektronski mikroskop (SEM), X-žarkovni difraktometer in stroj za testiranje mikrotrdote. Rezultati testa obrabe so pokazali, da ima hitrost-čas drsenja največji vpliv na avstenitno manganovo jeklo. Obdelava jekla v raztopini povečuje odpornost na obrabo pod povečano obremenitvijo, večjo hitrostjo in daljšim časom. Mikrostruktura odlitka je bila okarakterizirana z heterogeno porazdeljenimi kromovimi sekundarnimi karbidi, posledica pa je ugotovljena neenakomerna stopnja obrabe. Zaradi obdelave jekla HAMnS v raztopini, so se segregacijski karbidi raztopili pri $1050{ }^{\circ} \mathrm{C}$ in uniformno razporedili znotraj matrike mikrostukture po hitrem ohlajevanju z vodo na sobno temperaturo. To je tudi povzročilo uniformno in izboljšano odpornost na obrabo litega manganovega jekla. Ta raziskava jasno kaže, da obstaja neposredna povezava med sekundarnimi karbidi, njihovo porazdelitvijo in stopnjo obrabe.

\section{PODATKI O ČLANKU}

Ključne besede:

Manganovo jeklo

Značilnosti obrabe

Toplotna obdelava

Mikrostruktura

Trdota

*Kontaktna oseba:

jagunsoye@unilag.edu.ng

(Agunsoye, J.0.)

Zgodovina članka:

Prejet 18. novembra 2014

Popravljen 30. marca 2015

Sprejet 7. aprila 2015 


\section{References}

[1] Mokken, A.H. (1969). The use of stainless steels in the mining industry; In: Proceedings Symposium on Stainless steels, Johannesburg, 83-102.

[2] Agunsoye, J.O., Talabi, S.I., Abiona, A.A. (2013). On the comparison of microstructure characteristics and mechanical properties of high chromium white iron with the hadfield austenitic manganese steel, Journal of Minerals and Materials Characterization and Engineering, Vol. 1, 24-28, doi: 10.4236/immce.2013.11005.

[3] Studnicki, A., Kilarski, J., Przybył, M., Suchoń, J., Bartocha, D. (2006). Wear resistance of chromium cast iron research and application, Journal of Achievements in Materials and Manufacturing Engineering, Vol. 16, No. 1-2, 63-73.

[4] Agunsoye, J. (2009). The Wear Characteristics of Austenitic Manganese Steel Casting, PhD Thesis, University of Lagos, Nigeria.

[5] Balogun, S.A., Esezobor, D.E., Agunsoye, J.O. (2008). Effect of melting temperature on the wear characteristics of austenitic manganese steel, Journal of Minerals and Materials Characterization and Engineering, Vol. 7, No. 3, 277-289.

[6] Yan, W., Fang, L., Sun, K., Xu, Y. (2007). Effect of surface work hardening on wear behavior of Hadfield steel, Materials Science and Engineering: A, Vol. 460-461, 542-549, doi: 10.1016/i.msea.2007.02.094.

[7] Abbasi, M., Kheirandish, S., Kharrazi, Y., Hejazi, J. (2010). On the comparison of the abrasive wear behavior of aluminum alloyed and standard Hadfield steels, Wear, Vol. 268, No. 1-2, 202-207, doi: 10.1016/j.wear.2009. $\underline{07.010 .}$.

[8] Bouaziz, O., Allain, S., Scott, C.P., Cugy, P., Barbier, D. (2011). High manganese austenitic twinning induced plasticity steels: A review of the microstructure properties relationships, Current Opinion in Solid State and Materials Science, Vol. 15, No. 4, 141-168, doi: 10.1016/j.cossms.2011.04.002.

[9] Aribo, S., Alaneme, K.K., Folorunso, D.O., Aramide, F.O. (2010). Effect of precipitation hardening on hardness and microstructure of austenitic manganese steel, Journal of Minerals and Materials Characterization and Engineering, Vol. 9, No. 2, 157-164.

[10] Xu, Y., Chen, Y., Xiong, J., Zhu, J. (2001). Mechanism of strain-induced nanocrystallization of Hadfield steel under high energy impact load, Acta Metallurgica Sinica, Vol. 37, 165-70.

[11] Agunsoye, J.O, Ochulor, E.F., Talabi, S.I., Olatunji, S. (2012). Effect of manganese additions and wear parameter on the tribological behaviour of NFGrey (8) cast iron, Tribology in Industry, Vol. 34, No. 4, 239-246. 